\title{
TTW Model Assisted by Rotating Wheel Media to Improve Elementary Students' Critical Thinking Ability
}

\author{
*Nazila 'Ainur Rohmah ${ }^{1}$, Siti Masfuah², Deka Setiawan ${ }^{3}$ \\ 1,2,3Program Studi Pendidikan Guru Sekolah Dasar, Universitas Muria Kudus, Kudus, Indonesia
}

\section{A R T I C L E I N F O}

Article history:

1 Mei 2020 Received in

revised form

11 Juni 2020

Accepted 10 Juli 2020

Available online 25 Agustus

2020

\author{
Kata Kunci: \\ Berpikir kritis, TTW, roda \\ putar
}

Keywords:

Critical thinking, TTW,

rotating whee

\begin{abstract}
A B S T R A K
Rendahnya kemampuan berpikir kritis siswa menjad permasalah utama penelitian ini. Hal ini disebabakan proses pembelajaran yang masih teacher center belum student center sehingga siswa menjadi pasif dalam pembelajaran. Penelitian ini bertujuan untuk meningkatkan kemampuan berpikir kritis dan aktivitas belajar siswa melalui penerapan model Think Talk Write berbantuan media roda putar kelas IV SDN Talun 01 yang berjumlah 28 siswa. Jenis penelitian ini adalah Penelitian Tindakan Kelas. Penelitian ini berlangsung selama 2 siklus, setiap siklus terdiri dari 4 tahap, yakni perencanaan, pelaksanaan, observasi, dan refleksi. Variabel bebas dalam penelitian ini adalah model pembelajaran Think Talk Write berbantuan media roda putar dan variabel terikatnya adalah berpikir kritis. Instrumen dalam penelitian ini adalah instrumen tes, wawancara, observasi, dan dokumentasi. Teknik analisis data yang
\end{abstract} digunakan dalam penelitian ini berupa hasil analisis kuantitatif dan analisis kualitatif. Hasil penelitian tindakan kelas ini dapat dilihat dari tercapainya indikator keberhasilan sebagai berikut (1) berpikir kritis, ketuntasan klasikal siswa tahap prasiklus sebesar 62\% (kurang) terjadi peningkatan pada siklus I sebesar $72 \%$ (kurang) dan meningkat pada siklus II sebesar $85 \%$ (baik). (2) aktivitas belajar siswa ranah sikap siklus I sebesar 73\% (kurang) meningkat pada siklus II sebesar $86 \%$ (baik) dan aktivitas belajar siswa ranah keterampilan siklus I sebesar 74 (kurang) meningkat pada siklus II sebesar $87 \%$ (baik). Berdasarkan hasil penelitian, dapat disimpulkan bahwa penerapan model Think Talk Write berbantuan media roda putar dapat meningkatkan kemampuan berpikir kritis dan aktivitas belajar siswa pada tema 7 Indahnya Keragaman di Negeriku kelas IV SDN.

\section{A B S T R A C T}

This study aims to improve students' critical thinking skills and student learning activities. After they applied the Think Talk Write learning models assisted by rotating wheel media on IV-grade students of SDN Talun 01 with 28 research subjects. This type of research was classroom action research. The research was conducted in two cycles, each cycle consisted of 4 stages, namely, planning, implementing, observing, and reflecting. The independent variable in this study was the Think Talk Write learning model assisted by the rotating wheel media, and the dependent variable was the skill to think critically. The instruments in this study were tests, interviews, observation, and documentation instruments. Data analysis techniques used in this study were quantitative analysis and qualitative analysis. The results of this class action research can be seen from the achievement of the following indicators, namely (1) critical thinking skills, classical completeness of pre-cycle students by $62 \%$ (less) and increased on the first cycle by $72 \%$ (less), and increased in cycle II by $85 \%$ (good). (2) Student learning activities in the first cycle, attitude field, were $73 \%$ (less) and increased in the second cycle by $86 \%$ (good). Then, student learning activities in the cycle I, skills field were $74 \%$ (less) and increased in cycle II by $87 \%$ (good). Furthermore, it can be concluded that the application of the Think Talk Write learning model assisted with the 7th theme rotating wheel media about the diverse beauty in my country on IV-grade students of SDN. 


\section{Introduction}

The learning process to practice Higher Order Thinking Skills (HOTS) in the industrial era 4.0 uses 4C learning, including critical thinking, communication, collaboration, and creativity (Mubarok, 2019). Critical Thinking is currently a learning center that is being intensively implemented. Critical thinking is an activity that is carried out through a way of thinking about ideas or ideas related to the given concept or the problems described (Susanto, 2013; Ginting, 2019). From this explanation, critical thinking skills need to be developed in students. Through the ability to think critically, able to make it easier for students to understand and solve problems. The ability to think critically allows students to study problems faced systematically, face various challenges in an organized way, formulate innovative questions, and be able to design solutions to problems faced in an original and accountable manner. However, in reality, not all students have good critical thinking skills. This is evidenced by the fact that there are still many students who take part in the learning process using the memorization method so that students do not understand the learning material provided properly, besides that students also have difficulty expressing their ideas or ideas. This happens because students tend to only listen to the material presented by the teacher and students are not confident in expressing their opinions.

Based on the results of the pre-cycle conducted on fourth-grade students of SDN Talun 01, it can be said that the students' critical thinking skills are still low. The results of the observation show that there are still many students who are busy playing alone, talking with their friends, and not taking an active role during the learning process. This is because the existing facilities and infrastructure at school are still very limited so that the limitations of teachers in using learning models and media are not optimal. The teacher has tried to make learning interesting so that students are excited about the learning process, but the method used is not optimal, because it only uses conventional methods. The use of conventional methods makes students feel bored and discouraged in participating in the learning process. The learning process that occurs is only dominated by the delivery of material by the teacher so that learning tends to be more towards the teacher center (teacher-centered). The implementation of teacher-centered learning makes students reluctant and afraid to express their opinions, and less confident in their opinions because students are only accustomed to receiving information from the teacher without further seeking out and exploring their knowledge. In addition, when the teacher gives a problem, students still have difficulty solving the problem. This problem was also reinforced by the pre-cycle results given through the student's critical thinking ability test instrument and getting an average score of 62.3 (less). The data were taken from the number of grade IV students at SDN Talun 01, totaling 28 students, 7 students (20\%) passed, and 21 students $(80 \%)$ who failed.

Based on the description of the learning problems that occur as above, it can be said that students' thinking abilities are still low so that an effort is needed to improve the learning process carried out in these schools and later be able to improve critical thinking skills. One effort that can be done is by changing the learning process from a teacher center to a student center. These changes are implemented by using learning models that are innovative, creative, interesting, and can stimulate students' curiosity and critical thinking skills by applying cooperative learning models. The cooperative learning model that can be used is the Think Talk Write (TTW) learning model. The application of the Think Talk Write learning model is a solution offered based on real learning situations in the field that can train students to think about solving problems, foster curiosity, and student learning activities, to train students in improving critical thinking skills. (Huda, 2017; Winarti, 2018) argues that the Think Talk Write (TTW) model is a strategy that encourages and facilitates language training to think, speak, and then be able to write down topics and ideas smoothly. This is in line with the statement of Sim (Continak, 2016) which states that TTW is a cooperative learning model that aims to improve and develop students' creativity in critical thinking, work, and active communication through group discussions and presentations.

The TTW strategy can encourage students to think about solving problems, talk or discuss the problems given then write down the answers to these problems. The syntax in this model is think (train students to think about a problem using their language), talk (train students to discuss or exchange opinions with their group mates), write (train students to write down answers or opinions on problems that have been agreed by friends. one group) (Kerti, 2018). The learning process is expected to improve students' ability to think critically. The TTW learning model has several advantages including being able to sharpen the visual thinking skills of students themselves in more detail, developing students 'abilities in understanding teaching materials by giving questions and problems to develop students' critical and creative thinking skills. In addition, interacting and communicating in a group makes students more active in learning, and familiarizes students to communicate well with friends or teachers (Kusuma, 2016). 
In addition to using a learning model, a learning media is also needed so that it can help students remember the material being taught and improve their critical thinking skills. The use of instructional media will arouse student interest and motivation, reduce verbalism, as a channel of information, provide encouragement to students, and increase knowledge retention in learning and the interaction between teachers and students so that learning activities are more effective and efficient (Lisiswanti, 2016; Anam, 2015). In this study, the selected learning media uses rotating wheel media. The spin wheel is a media in the form of a game. The media is a tool in the form of an illustrated circle that is rotated, moves on its axis until it stops in one part of the image (Hamzah, et al, 2019). The circle is made of wooden plywood. The circle is divided into 6 parts, each part contains colors that attract various kinds of diversity in Indonesia, as well as a question card that contains questions on problem topics to stimulate students to think (Novianti, 2015). Think Talk Write learning model assisted by rotating wheel media is expected to train students in learning to solve problems both individually and in groups through the given question cards so that it is expected that students' critical thinking can improve. Besides that, it can create a fun, interesting, and fun learning process. Because with the help of this rotating wheel, students can learn while playing.

Some of the studies that support this research are research conducted by (Gunawan et al., 2016) which states that the TTW model can improve critical thinking skills and learning outcomes of fourth semester II students. The increase occurred because students were motivated to take part in learning through discussion with activities to think (think), speak (talk), and write (write). (Naimnule et al., 2016) stated that the TTW model was able to increase student activity and cognitive learning outcomes. Through the application of the TTW model, students are trained to be active in thinking (think) by analyzing problems given by the teacher, then students are trained to talk by discussing with their groups, and finally, students are trained to make summaries or small notes (write) by analyzing material which has been discussed in writing. (Merrante et al., 2019) stated that the TTW model can improve critical thinking skills and learning outcomes of fourth-grade elementary school students. So, in the TTW model, the teacher facilitates students in preparing a problem to hone students' critical thinking skills.

Research related to the application of rotating wheel learning media has been carried out and has succeeded in overcoming this problem. Research conducted by (Kurniadewi, 2019) states that the use of smart puzzle rotating wheel media can improve learning achievement. (Rina \& Sukanti, 2016) state that learning with rotating wheel media can increase student learning activities. (Hamzah et al., 2020) stated that learning using rotating wheel media can increase student learning motivation.

The difference between the previous research and this research is that the previous research only applied the Think Talk Write model without using learning media, while in this study the researcher used the Think Talk Write model assisted by the rotating wheel media. This rotary wheel learning media is not only a game but is equipped with question cards that can stimulate students to practice critical thinking.

Based on the above background, a study was conducted to describe the improvement of students' critical thinking skills and learning activities through the Think Talk Write model assisted by the rotating wheel media theme 7 The Beauty of Diversity in My Country, grade IV SDN Talun 01.

\section{Methodology}

This type of research is Classroom Action Research. The implementation of this classroom action research was carried out in February 2020 in grade IV SDN Talun 01 with 28 research subjects. The research lasted for 2 cycles using the PTK design from Kemmis and Mc. Traggart (Arikunto, 2012). Each cycle consists of 4 stages, namely planning, implementing, observing, and reflecting. This research is focused on improving students' critical thinking skills and learning activities through the application of the Think Talk Write model assisted by rotating wheel media. Indonesia. The independent variable in this study is the Think Talk Write model assisted by the rotating wheel media and the dependent variable in this study is the critical thinking ability and student learning activities.

The instrument in this study was a written test instrument in the form of an essay totaling 10 numbers to measure students' critical thinking skills according to (Susanto's, 2013) indicator on the subject of the Beauty of Diversity in My Country, pre-cycle interviews with grade IV teachers of SDN Talun 01 and grade IV students of SDN Talun 01. To get information about learning problems in this class, observation sheets to measure student learning activities in the realm of attitudes and skills during the learning process are in accordance with (Hamalik's, 2015) indicators and documentation to record the learning process. The data analysis technique in this research is in the form of quantitative techniques through descriptive analysis of the results of critical thinking as measured by test instruments and student activities using observation sheet instruments, while qualitative techniques are categorizing/classifying the results of critical thinking and student activities in the category very good, good, sufficient. and less. In 
this classroom action research, it is said to be successful if the critical thinking skills and learning activities of students with PPKn and Indonesian language content in grade IV SDN Talun 01 have increased. As for the criteria for the success indicators set, namely the improvement of critical thinking skills and student learning activities, namely obtaining a classical score of $\geq 75$ in the sufficient category, it can be said that the research through the TTW model assisted by the rotary wheel media was successful.

\section{Finding and Discussion}

\section{Result}

This classroom action research consists of the pre-cycle stage (2 November 2019), the first cycle (19-20 February 2020), and the second cycle (26-27 February 2020) to measure students' critical thinking skills and student learning activities on the content of PPKn and Indonesian class IV SDN Talun 01 with 28 students as subjects starting from the pre-cycle stage to cycle I and cycle I to cycle II. After finishing the lesson, students are given evaluation test questions to measure their critical thinking skills in each cycle at the second meeting. This critical thinking ability consists of indicators (1) providing simple explanations, indicators (2) building basic concept skills, indicators (3) concluding, indicators (4) providing further explanations, and indicators (5) setting strategies and tactics. The following are the results of the students' critical thinking ability scores for each indicator that can be seen in Figure 1.

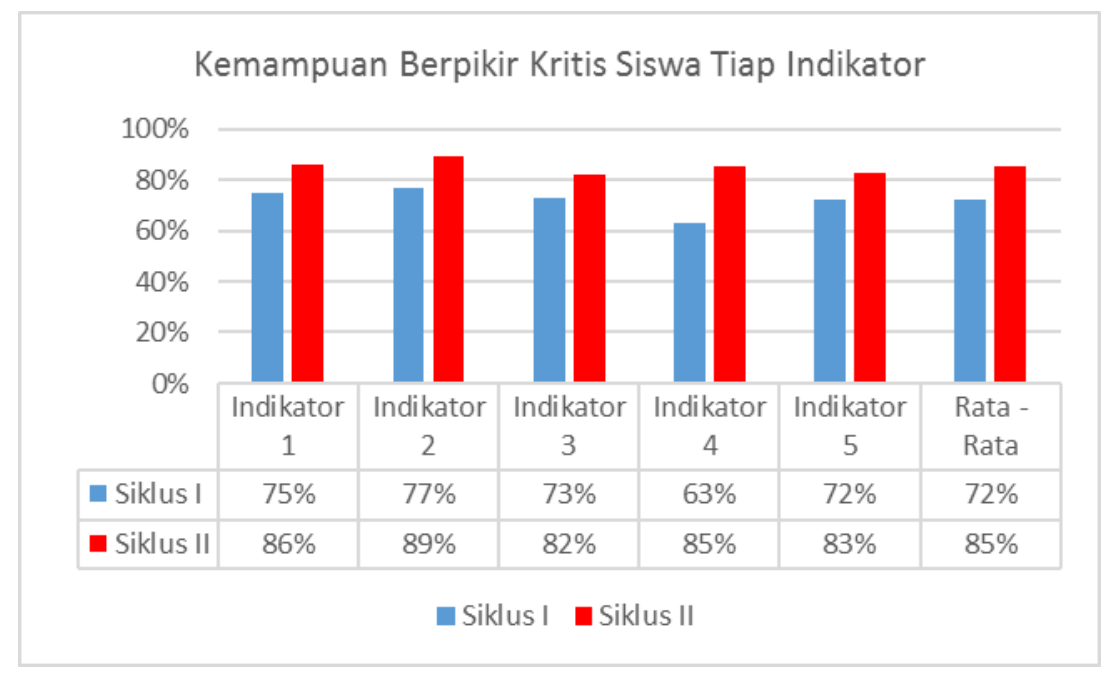

Figure 1.The results of the students' critical thinking ability scores for each indicator

Based on Figure 1, it can be concluded that the results of students' critical thinking ability scores for each indicator in cycle I obtained a percentage of $72 \%$ (less) and an increase in cycle II, namely obtaining a percentage of $85 \%$ (good). So, it can be concluded that the increase in students' critical thinking skills from cycle I to cycle II is $13 \%$. This shows that the application of the Think Talk Write model assisted by rotating wheel media can improve students' critical thinking skills and has met the established success indicators, namely $\geq 75$ with sufficient criteria, so this research is said to be successful.

In addition to measuring critical thinking skills, this study also measures student learning activities. Student learning activities in this study are divided into two, namely student learning activities in the realm of attitudes including (1) visual activities, (2) oral activities, (3) listening activities, and (4) emotional activities and student learning activities in the realm of skills including (1) writing activities, (2) mental activities and (3) metric activities.

Student learning activities in the realm of this attitude consist of indicators (1) visual activities, indicators (2) oral activities, indicators (3) listening activities, and indicators (4) emotional activities. The following are the results of observations of student learning activities in the domain of each indicator's attitude can be seen in Figure 2. 


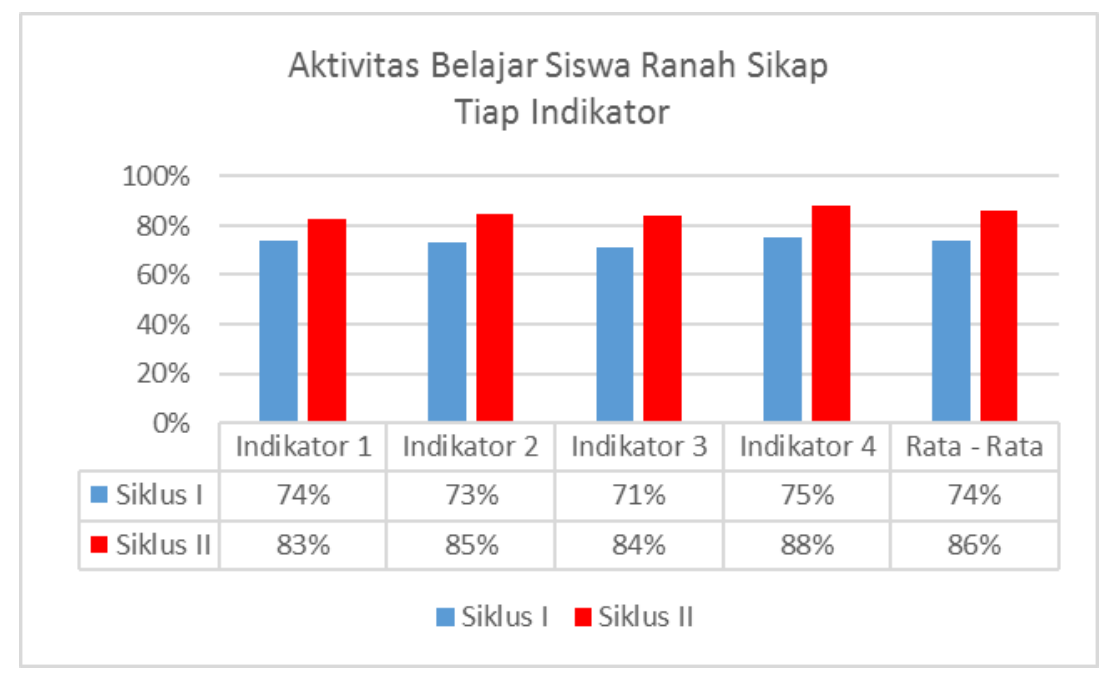

Figure 2. Student Learning Activities in the Domain of Attitudes for Each Indicator

Based on Figure 2, it can be concluded that the results of observations of student learning activities in the domain of attitudes of each indicator in cycle I obtained a percentage of $74 \%$ (less) and an increase in cycle II, namely obtaining a percentage of $86 \%$ (good). So, it can be concluded that the increase in student learning activities in the realm of attitude from cycle I to cycle II is $12 \%$. This shows that the application of the Think Talk Write model assisted by rotary wheel media can improve student learning activities in the realm of attitudes and has met the established success indicators, namely $\geq 75$ with sufficient criteria, so this research is said to be successful.

Students' learning activities in the realm of skills consist of indicators (1) writing activities, indicators (2) mental activities, and indicators (3) metric activities. The following are the results of observations of student learning activities in the realm of skills for each indicator that can be seen in Figure 3.

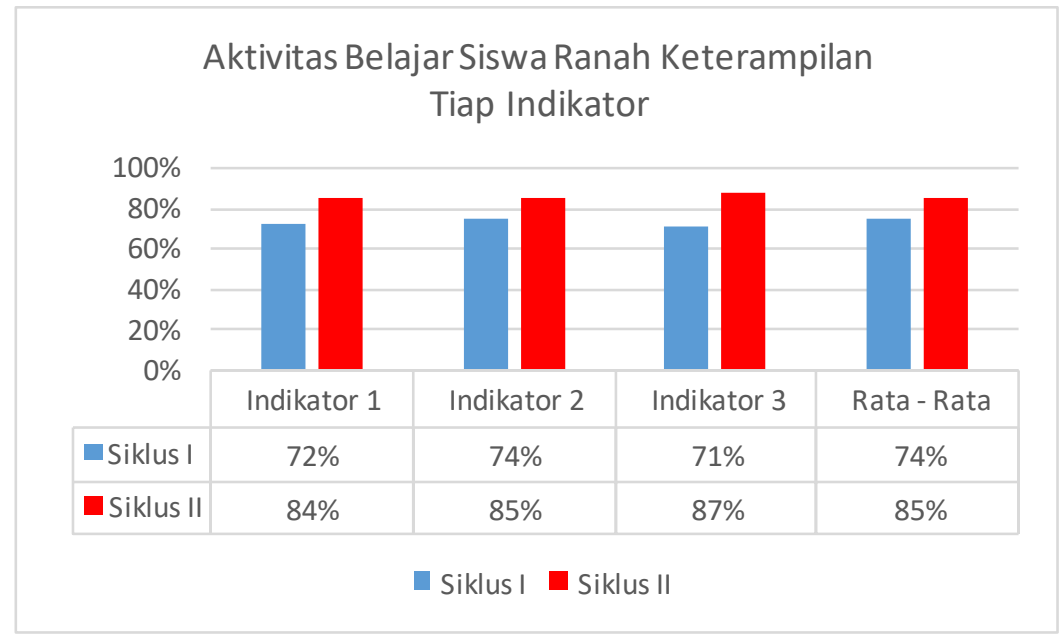

Figure 3. Student Learning Activities in the Areas of Skills for Each Indicator

Based on Figure 3, it can be concluded that the results of observations of student learning activities in the realm of skills for each indicator in cycle I obtained a percentage of $74 \%$ (less) and an increase in cycle II, namely obtaining a percentage of $85 \%$ (good). So, it can be concluded that the increase in student learning activities in the realm of skills from cycle I to cycle II is $11 \%$. This shows that the application of the Think Talk Write model assisted by rotating wheel media can improve student learning activities in the realm of skills and has met the established success indicators, namely $\geq 75$ with sufficient criteria, so this research is said to be successful. 


\section{Discussion}

The students' critical thinking skills for each indicator are described as follows, namely indicator (1) provides a simple explanation. In cycle I learning, a percentage of $75 \%$ is obtained because students are less able to identify or answer a problem given by the teacher, students are less able to provide reasons for the answers they have, students are only able to answer these problems briefly. Then in cycle II learning obtained a percentage of $86 \%$ because the teacher provides guidance and direction to students, to be able to encourage students to answer problems and be able to make students brave and confident to give reasons for the answers they have, but there are still some students who have difficulty because students are not used to critical thinking. This agrees with (Sholekhah et al., 2019) that providing simple explanations can be by giving questions to students, such as worksheets and evaluation questions. By working on worksheets in each meeting with one group of friends and working on evaluation questions in each cycle at the second meeting, students can improve their critical thinking skills.

Indicator (2) builds basic skills. In the learning cycle, I obtained a percentage of $73 \%$ because students are not careful in solving a problem, students are not used to writing things that are considered important, students do not consider whether the source obtained is reliable or not. Then in cycle II learning obtained a percentage of $89 \%$ because the teacher gave advice and directions to students to read with focus so that students began to be careful in solving problems, students were accustomed to noting things that were considered important and students were able to consider whether the sources were obtained it can be trusted or not. This agrees with (Adiwijaya et al., 2016) that building basic skills can ask students to reveal or explain learning material according to their respective understanding, this can train students to solve difficulties or solve these problems.

Indicator (3) concludes. In the learning cycle, I obtained a percentage of $73 \%$ because students could not conclude learning material using their sentences or were still motivated by books, in reflection activities students were less able to conclude the material that had been studied. Then in cycle II learning obtained a percentage of $82 \%$ because the teacher provides direction and guidance to students to be confident in conveying their opinions or ideas so that students can conclude the material that has been studied using their sentences even though they are short. This agrees with (Rusnah, 2018) that concluding is an activity that is often carried out by students. This concluding activity can be in the form of making a summary or expressing opinions verbally about the learning material that has been taught by the teacher, this can require students to understand the material being taught.

Indicator (4) provides further explanation. In the learning cycle, the percentage was $63 \%$ because students were less able to differentiate between assumptions, students still had difficulty explaining these assumptions. Because indicators provide further explanation, this requires critical thinking and involves students as thinkers, not as someone being taught. Then in the second cycle of learning, it obtained a percentage of $85 \%$ because the teacher trained and guided students to find a reason so that it made students able to distinguish which assumptions were correct and which were wrong and were able to provide a reason for these assumptions. This agrees with (Haryanti, 2017) that a person is said to have the ability to think critically if that person can provide an answer that is reflective, productive, and evaluative to a problem at hand.

Indicators (5) set strategy and tactics. In the learning cycle, I obtained a percentage of $72 \%$ because students still have difficulty when asked by the teacher to carry out group discussions to solve problems. Then in cycle II learning got a percentage of $83 \%$ because the teacher gave advice and invited students to read the reading text or learning material and find solutions to these problems. Through reading activities, students can find students' strategies and tactics, besides that students are also used to solving problems through discussion. This agrees with (Hardiyanto, 2018) that arranging strategic planning and tactics through problem-based learning can require students to complete problem-solving skills.

In addition to measuring critical thinking skills, this study also measures observations of student learning activities. Student learning activities in this study are divided into two, namely student learning activities in the realm of attitudes including (1) visual activities, (2) oral activities, (3) listening activities, and (4) emotional activities and student learning activities in the realm of skills including (1) writing activities, (2) mental activities and (3) metric activities. Observation of student learning activities in the realm of attitudes for each indicator will be explained as follows.

Indicator (1) visual activities, carried out when students read the material to be studied, and when students pay attention to the teacher delivering the learning material. In cycle I learning, there is a percentage of $74 \%$ because there are still many students who do not pay attention to the teacher when delivering learning material, students are still busy talking with their friends. Then in cycle II learning got a percentage of $83 \%$ because the teacher advised students to pay attention when the teacher delivered the 
learning material and the teacher provided the material that had to be read by the students, to make students motivated and willing to do the teacher's orders to read the learning material provided by the teacher calmly and serious. This agrees with (Hadini, 2017) that reading activities can encourage, stimulate, and facilitate student memory.

Indicator (2) oral activity, carried out when students ask questions to friends and the teacher, and when students answer questions from friends and the teacher. In the cycle, II learning obtained a percentage of $73 \%$ because students still look shy and do not have confidence asking questions during the learning process. Then in cycle II learning obtained a percentage of $85 \%$ because the teacher often provokes students to express their opinions by asking questions to students, thus making students motivated and many students who have dared to be confident in answering questions given by the teacher and have been actively asking the teacher and his friends. This agrees with (Pratiwi et al., 2018) that from an early age students must be motivated or trained to do activities together or in groups to avoid selfish attitudes that exist in students.

Indicator (3) listening activities, carried out when students listen to the teacher's explanation and when students listen to other groups who are making presentations. In the learning cycle, I obtained a percentage of $71 \%$ because there are still many students who are busy talking with their friends and do not pay attention or listen to the learning process, both the teacher and their friends who are making presentations. Then in cycle II learning obtained a percentage of $84 \%$ because the teacher often gives directions and advice to students not to be noisy and focus on listening to the explanation of the material by the teacher while participating in the learning process, so that many students are motivated and all students listen when someone is delivering learning material in front. class, this agrees with (Lubis, 2018) that through listening activities can make students more enthusiastic and enthusiastic in concluding the contents of the stories that are heard.

Indicator (4) emotional activity, carried out when students participate in the learning process from beginning to end with enthusiasm. In the first cycle of learning, a percentage of $75 \%$ was obtained because during the learning process many students felt bored and even played alone. Then in cycle II learning gets a percentage of $88 \%$ because the teacher often gives advice and guidance to students to participate in the learning process from start to finish with enthusiasm, this makes students motivated and willing to follow directions from the teacher to follow the learning process from start to finish calmly and excited. This agrees with (Haryanti, 2017) that emotional activities include courage, never giving up, and being able to show a calm attitude in following the learning process.

Observation of student learning activities in the realm of each indicator will be explained as follows.

Indicators (1) writing activities are carried out when students write down the conclusions of the material that has been studied and when students write down the diversity that exists in Indonesia including ethnicity, regional languages, traditional clothing, and traditional houses. In the learning cycle, I obtained a percentage of $72 \%$ because students were not used to recording learning material. Then in cycle II learning obtained a percentage of $84 \%$ because the teacher trains students to actively summarize the most important parts of the material that has been taught to make learning easier, to be able to make students follow the teacher's orders by practicing summarizing the material that has been learned and students are accustomed to taking notes the most important parts of the learning material. This agrees with (Amilia, 2018) that writing activities have a very important role because through writing skills it can help students to make it easier to remember mastery of theory.

Indicator (2) mental activities, carried out when students respond to the results of other group discussions and when students dare to convey conclusions from the material that has been taught. In the first cycle of learning, it obtained a percentage of 74\% because students only listened to their friends who made presentations, students did not want to respond to the presented results and did not want to convey learning conclusions. In cycle II learning, a percentage of $85 \%$ is obtained because the teacher gives appreciation in the form of additional value for students who dare to answer or argue in front of the class, to make students interested and excited in expressing their opinions. This agrees with (Agustin, 2017) that mental activities can make students more active and confident in following the learning process from beginning to end. Because with confidence, students can get the additional value promised by the teacher for their activeness and participation in the learning process.

Indicator (3) metric activity, carried out when students work on evaluation questions, worksheets, and when students actively participate in playing wheel media games. In the learning cycle, I obtained a percentage of $71 \%$ because many students enjoy playing the media, but when working on the worksheets they do not participate in the discussion. Then in cycle II learning obtained a percentage of $87 \%$ because the teacher allowed students to learn while playing the rotating wheel media on the condition that they had to answer the question cards contained in the media, so that they were able to make students more enthusiastic in discussing and active in answering the questions. is in the game of learning media and can 
encourage students to be active in thinking. This agrees with (Istiqomah, 2016) that outbound activities can develop children's social-emotional development, outbound activities in this study are the learning process through learning media. The learning process like this is what makes students more interested because students do not only learn but can also play so that students do not feel bored and mo notonous in following the learning process.

Based on the description above, it is concluded that the application of the Think Talk Write model assisted by rotating wheel media in grade IV SDN Talun 01 can improve students' critical thinking skills and student learning activities. This study measures students' critical thinking skills and learning activities of fourth-grade elementary school students on the beauty of diversity in my country using the TTW learning model assisted by rotary wheel media. In the application of the Think Talk Write model, it is adjusted to the syntax of this learning model, namely (think) the teacher trains students to think individually or in groups, (talk) the teacher trains students to discuss and dare to express their opinions in front of friends or teachers, and (write) the teacher trains students to summarize or record the results of the discussion in writing and then present it to the class. So that in the learning process that takes place the teacher can provide direct experience to students and make it easier for students to solve problems, and be able to improve critical thinking skills and student learning activities. (Farida et al., 2020) stated that the application of Think Talk Write (TTW) can improve learning activities and learning outcomes. This study also shows that the application of the TTW model can improve student activity and learning outcomes (Ratih et al., 2017). In implementing this Think Talk Write model, teachers can make it easier for students to increase their learning activities. The Think Talk Write learning model, in general, has several advantages, including being able to develop students' ability to analyze, ask and answer and write, and be able to develop ideas or ideas that students have which can then be conveyed orally (Yanuarta, 2017).

The thing that distinguishes this research from previous research is that in this study, the researcher modified the Think Talk Write model with a rotating wheel game media containing question cards in the form of questions where there are rewards and punishments given in accordance with the learning material that has been taught to class students. IV SDN Talun 01. In this activity, the use of rotating wheel media is not only a medium for a game but also to encourage students to think critically. This media is a game that can train a child's mindset in solving a problem in the form of questions given by the teacher (Ardiansyah, 2018). This rotating wheel learning media has advantages including this media that is easy to make, attractive, can stimulate student curiosity, and can be used for all lesson content in accordance with the teaching material and learning objectives to be achieved (Simbolon, 2019). The use of attractive and innovative learning models combined with learning media that is in accordance with the characteristics of elementary school students makes the learning process more effective and efficient so that the learning objectives to be achieved can be achieved. So, from the above explanation, it can be seen that the critical thinking skills and learning activities of students through the application of the Think Talk Write model assisted by rotating wheel media can increase.

The results of this study are supported by previous research. Research conducted by (Asri, 2017) states that the application of Think Talk Write (TTW) can improve critical thinking skills. Then similar research was also carried out by (Lesmana, 2019) which showed that the application of the TTW model can improve the critical thinking skills of elementary students. Then research related to the use of rotary wheel learning media has also been widely carried out. Research conducted by (Eeliana, 2019) shows that the use of rotating wheel media has a positive effect on student achievement and cooperation attitudes. Other supporting research was also conducted by (Rahmawati, 2020) which shows the results that the use of rotary wheel learning media can improve learning outcomes for elementary students.

From this research it can be concluded that the application of the Think Talk Write learning model is very suitable to be applied in elementary schools, integrated with the use of rotary wheel learning media to make the learning process more interesting and not boring so that the learning process is more meaningful. This research implies that it can provide fresh air in the world of education, especially in learning in elementary schools. This can be seen from the results of the study showing that the application of the TTW model assisted by a rotary wheel can improve students' critical thinking skills and an increase in student activity in learning. The use of this model guides students on how students are trained to think about a problem using their language, are trained to discuss or exchange opinions with their group friends, are trained to write down answers or opinions on problems that have been agreed by the group friends. Integrated with the rotating wheel media certainly makes students interested in students to learn. Through this model and media, students are sensitive to problems and try to find solutions to solve existing problems that can be accepted and accounted for. In addition, through this learning model and 
media, it can be a solution to problems in learning so that learning takes place well and the formation of superior future generations.

\section{Conclusion}

Based on the results and discussion, it is concluded that the increase in students' critical thinking skills after applying the Think Talk Write model assisted by the theme of the spin-wheel media 7 The Beauty of Diversity in My Country in grade IV SDN Talun 01 cycle I obtained a percentage of 72\% (less) and experienced an increase in cycle II, namely obtaining a percentage of 85\% (good). Then the incr ease in student learning activities in the realm of attitudes after implementing the Think Talk Write model assisted by the rotating wheel media theme 7 The Beauty of Diversity in My Country in grade IV SDN Talun 01 cycle I obtained a percentage of $74 \%$ (less) and experienced an increase in the second cycle, namely obtaining a percentage of $85 \%$ (well). The increase in students' learning activities in the realm of skills after applying the Think Talk Write model assisted by the theme of the wheel 7 The Beauty of Diversity in My Country for fourth-grade students of SDN Talun 01 cycle I obtained a percentage of 74\% (less) and experienced an increase in cycle II, namely obtaining a percentage of $86 \%$ (well). In general, the application of the Think Talk Write learning model assisted by the Spin Wheel Media improves students' critical thinking skills and student learning activities.

\section{Reference}

Adiwijaya, H., Suarsini, E., dan Lukiati, B. (2016). Penerapan Pembelajaran Reciprocal Teaching Bebantuan Peta Konsep Untuk Meningkatkan Kemampuan Berpikir Kritis Sisws Pada Pembelajaran Biologi. Jurnal Pendidikan, Vol.1, No. 32, Hlm. 2379-2387. http://dx.doi.org/10.17977/jp.v1i12.8359

Agustin, M., Yensy, N, A. dan Rusdi (2017). Upaya Meningkatkan Aktivitas Belajar Siswa dengan Menerapkan Model Pembelajaran Problem Posing Tipe Pre Solution Posing di SMP Negeri 15 Kota Bengkulu. Jurnal Penelitian Pembelajaran Matematika Sekolah (JP2MS), Vol. 1, No. 1, Hlm. 67-72. https://doi.org/10.33369/jp2ms.1.1.66-72

Aliwanto (2017). Analisis Aktivitas Belajar Siswa. Jurnal Konseling GUSJIGANG, Vol. 3, No. 1, Hlm. 64-71.

Amilia, Fitri. (2018). Pemahaman dan Habituasi Untuk Membangun Kompetensi Menulis Praktis dan Ilmiah. Jurnal Bahasa, Sastra dan Pengajarannya, Vol. 6, No. 1, Hlm. 22-31. http://dx.doi.org/10.30651/lf.v2i1.1401

Ardiansyah, Muhammad Zulkifi Fakhrizal Dan Mustaji. 2018. Pengembangan Media Permainan Roda Putar Materi Pokok Ekosistem Dalam Mata Pelajaran Ilmu Pengetahuan Alam Bagi Siswa Kelas V Sekolah Dasar. Jurnal Mahasiswa Teknologi Pendidikan, Volume 9 Nomor 2, Hlm 2-10. https://jurnalmahasiswa.unesa.ac.id/index.php/jmtp/article/view/25180

Arikunto, Suharsimin. 2012. Penelitian Tindakan Kelas. Jakarta: Bumi Aksara.

Asri, I, G, A, A. (2017). TTW Melalui Lesson Study Untuk Meningkatkan Keaktifan dan Kemampuan Berpikir Kritis Mahasiswa PG PAUD. Jurnal Pendidikan Media Edukasi, Vol.1, No. 1, HIm. 16-21. https://www.jurnal.undhirabali.ac.id/index.php/jmk/article/view/254

Eeliana, Vikha., dkk. 2019. Pengaruh Model Numbered Head Together (Nht) Berbantu Media Roda Putar Terhadap Prestasi Belajar Dan Sikap Kerja Sama Siswa Kelas IV SDN 2 Ngampel Kulon. Konferensi Ilmiah Mahasiswa HNISSULA, Hlm 295-303. $\quad$ http://lppmunissula.com/jurnal.unissula.ac.id/index.php/kimuhum/article/view/8141

Farida, I., Ningsih, K., dan Titin. (2020). Meningkatkan Aktivitas dan Hasil Belajar Siswa Melalui Model Kooperatif TTW Berbantuan Media Leaflet. IJIS Edu, Vol.2, No.1, HIm. 7-18. http://dx.doi.org/10.29300/ijisedu.v2i1.2714

Ginting, Raja Manik. 2019. Analisis Kemampuan Berfikir Kritis. Research Gate, Hlm 1-9.

Gunawan, I.W., Dibia I.K., dan Mahadewi, L.P.P (2016). Penerapan Model Think Talk Write Untuk Meningkatkan Kemampuan Berpikir Kritis dan Hasil Belajar IPA. E-Journal PGSD Universitas Pendidikan Ganesha, Vol. 4, No. 1, Hlm. 1-12. http://dx.doi.org/10.23887/jjpgsd.v4i1.7515

Hadini, Nining. (2017). Meningkatkan Kemampuan Membaca Anak Usia Dini Melalui Kegiatan Permainan Kartu Kata di TK Al-Fauzan Desa Ciharashas Kecamatan Cilaku Kabupaten Cianjur. Jurnal 
$\begin{array}{lllllll}\text { EMPOWERMENT, } \quad \text { Vol. } & \text { 6, } & \text { No. } & 1, & \text { Hlm. }\end{array}$ https://doi.org/10.22460/empowerment.v6i1p\%25p.370

Hamalik, Oemar. (2015). Kurikulum dan Pembelajaran. Jakarta: Bumi Aksara

Hamzah, Utami, L, S., dan Zulkarnain (2020). Pengembangan Media Pembelajaran Roda Putar Fisika Untuk Meningkatkan Motivasi Belajar Siswa. Jurnal Hasil Kajian, Inovasi dan Aplikasi Pendidikan Fisika, Vol. 5, no. 2, Hlm. 77-81. https://doi.org/10.31764/orbita.v5i2.1192

Hardiyanto, W., dan Santoso, R.H. (2018). Efektivitas PBL Setting TTW dan TPS ditinjau dari Prestasi Belajar, Berpikir Kritis dan Self-Efficacy Siswa. Jurnal Riset Pendidikan Matematika, Vol. 5, No. 1. Hlm. 116-126. https://doi.org/10.21831/jrpm.v5i1.11127

Haryanti, Y.D. (2017) Model Problem Based Learning Membangun Kemampuan Berpikir Kritis Siswa Sekolah Dasar. Jurnal Cakrawala Pendas, Vol, 3, No. 2, Hlm 57-63. http://dx.doi.org/10.31949/jcp.v3i2.596.

Huda, Miftahul. 2017. Model-Model Pengajaran dan Pembelajaran. Yogyakarta: Pustaka Belajar.

Istiqomah N., Lathif, M.A., dan Khutobah (2016). Peningkatan Perkembangan Sosial dan Emosional Melalui Kegiatan Outbound Pada Anak Kelompok B di TK Asy-Syafa'ah Jember Tahun Pelajaran 2015/2016. Jurnal Edukasi UNEJ, Vol. 3, No. 2, Hlm. 19-21. https://doi.org/10.19184/jukasi.v3i2.3524.

Kerti, I Wayan. 2018. Penerapan Strategi Pembelajaran Think Talk Write Bermedia Gambar Untuk Meningkatkan Aktivitas Belajar dan Keterampilan Menulis Puisi Siswa. Jurnal Ilmu Pendidikan, $\begin{array}{llllll}\text { Volume } & 1 & \text { Nomor } & 2, & \text { Hlm } & \text { 87-96. }\end{array}$ http://jayapanguspress.penerbit.org/index.php/cetta/article/view/50

Kurniadewi, N (2019). Penggunaan Media Roda Putar Puzzle Pintar Untuk Meningkatkan Hasil Belajar Mata Pelajaran IPS Siswa SD. Jurnal TEKNODIK, Vol. 23, No. 1, HIm. 79-89. https://118.98.227.127/index.php/jurnalteknodik/article/view/335.

Kusuma, Jaka Wijaya. 2016. Pengaruh Pembelajaran Think Talk Write (TTW) Terhadap Hasil Belajar Mahasiswa Stie Bina Bangsa Pada Mata Kuliah Matematika Ekonomi. Matematika Jurnal, Volume 3 Nomor 2, Hlm 36-47. https://ejournal.stkipbbm.ac.id/index.php/mtk/article/view/97

Lesmana, I., Wahyudi., dan Indarin, E. (2019). Penerapan TTW dengan Roda Matika Untuk Meningkatkan Kemampuan Berpikir Kritis Siswa SD. Jurnal Pendidikan Tambusai, Vol. 3, No. 3, Hlm. 795-802. https://www.jptam.org/index.php/jptam/article/download/284/262.

Lubis, R.S., dan Rosmaini (2018). Peningkatan Keterampilan Menyimpulkan Isi Berita Menggunakan Media Audio Visual Siswa Kelas VIII di MTs Negeri 2 Medan Tahun Pembelajaran 2018/2019. Terakreditasi Kemenristekdikti Nomor: $34 / E / K P T / 2018, \quad$ Hlm. https://doi.org/10.24114/bss.v8i1.12935

Merrante, C.T., Relmasira, S.C., dan Hardini A.T.A (2019). Penerapan Model TTW Untuk Meningkatkan Hasil Belajar dan Berfikir Kritis Siswa Kelas IV SD. Jurnal Pendidikan Tambusai, Vol. 3, No. 4, Hlm. 928-935. https://doi.org/10.31004/jptam.v3i2.298

Mubarok, H (2019). High Order Thinking Skill dalam Pembentukan Karakter Siswa Sekolah Dasar di Era Industry 4.0. Jurnal Elementary, Vol. 7, No. 2, Hlm. 215-230. http://dx.doi.org/10.21043/elementary.v7i2.6107

Naimnule, L., Oetpah, V., dan Sila, V, U, R (2016). Peningkatan Aktivitas dan Hasil Belajar Kognitif Siswa Melalui Penerapan Model Pembelajaran Think Talk Write (TTW) di SMUK. Jurnal Pendidikan, Vol. 1, No. 10. Hlm. 2050-2053. http://dx.doi.org/10.17977/jp.v1i10.7622

Novianti, Ria. 2015. Pengembangan Permainan Roda Putar Untuk Meningkatkan Kemampuan Berhitung Angka Anak Usia 5-6 Tahun. Educhild, Volume 4 Nomor 1, Hlm 56-63. http://dx.doi.org/10.33578/jpsbe.v4i1.2803

Pratiwi, I.A., Ardianti, S.D., dan Khanzunnudin, M., (2018). Peningkatan Kemampuan Kerjasama Melalui Model Project Based Learning (PjBL) Berbantuan Metode Edutainment Pada Mata Pelajaran Ilmu Pengetahuan Sosial. Jurnal Refleksi Edukatika, Vol. 8. No. 2, Hlm. 178-182. https://doi.org/10.24176/re.v8i2.2357 
Rahmawati, Anita., Dkk. 2020. Implementasi Model Pembelajaran Numbered Head Together Berbantuan Media Roda Putaruntuk Meningkatkan Hasil Belajar Siswa. Journal On Education, Volume 2 Nomor 4, Hlm 283-296. https://doi.org/10.31004/joe.v2i4.321

Ratih, R., Sudin, A., dan Hanifah, N. (2017). Penerapan Strategi Cooperative Learning Tipe TTW Untuk Meningkatkan Aktivitas dan Hasil Belajar Siswa. Jurnal Pena Ilmiah, Vol. 2, No. 1, Hlm. 1190-1200. https://doi.org/10.17509/jpi.v2i1.10581

Rina dan Sukanti (2016). Penerapan Pembelajaran TGT dengan Roda Putar Untuk Meningkatkan Aktivitas Belajar Akuntansi Siswa SMKN 1 Tempel. Jurnal Pendidikan Akuntansi Indonesia, Vol. X1V No. 1, HIm. 35-44. https://doi.org/10.21831/jpai.v14i1.11365

Rusnah., dan Mulya, O.T. (2018). Meningkatkan Keterampilan Berpikir Kritis Siswa Melalui Pendekatan Saintifik di Sekolah Dasar. Jurnal Gentala Pendidikan Dasar, Vol. 3, No. 2, Hlm. 239-256. https://doi.org/10.22437/gentala.v3i2.6760

Sholekhah, K., Roysa, M., dan Masfuah, S. (2019). Penerapan Model Mind Mapping Berbantuan Media Pohon Ajaib Pada Siswa Tema 6 Cita-Citaku Kelas IV Sekolah Dasar. Jurnal Prakarsa Paedagogia, Vol.2, No. 2, Hlm. 213-229. https://doi.org/10.24176/jpp.v2i2.4523

Simanjuntak, Maslina. 2016. Model Pembelajaran Kooperatif Think-Talk-Write (Ttw) Dan Software Autographdalam Mempersiapkan Pendidik Matematika Menghadapi Masyarakat Ekonomiasean (Mea). Ejournal UKI, $\quad$ Volume $9 \quad$ Nomor $\quad 2, \quad$ Hlm $\quad$ 71-80. http://ejournal.uki.ac.id/index.php/jdp/article/view/339

Simbolon, Redina. 2019. Penggunaan Roda Pintar Untuk Kemampuan Membaca Anak. Jurnal Pendidikan dan Pengajaran Guru Sekolah Dasar (JPPGuseda), Volume 2 Nomor 2, Hlm 66-71. https://doi.org/ 10.33751/jppguseda.v2i2.1448

Susanto, Ahmad. 2016. Teori Belajar dan Pembelajaran di Sekolah Dasar. Jakarta: Prenadamedia Group.

Winarti, Asih. 2018. Model Pembelajaran Think Talk Write Meningkatkan Prestasi Belajar Mata Pelajaran IPA SD. Jurnal Pendidikan: Riset \& Konseptual, Volume 2 Nomor 3, Hlm 232-238. http://journal.unublitar.ac.id/pendidikan/index.php/Riset_Konseptual/article/view/56.

Yanuarta, Lidya., dkk. 2017. Pengembangan Karakter Dan Hasil Belajar Kognitif Siswa Dengan Pembelajaran Think Talk Writedipadu Problem Based Learning. Jurnal Pendidikan: Teori, Penelitian dan Pengembangan, $\quad$ Volume $2 \quad$ Nomor $\quad 2, \quad$ Hlm $\quad$ 192-198. https://media.neliti.com/media/publications/175469-ID-none.pdf 